and in many of the materials cited in the bibliography of that substantial text.

2. I teach a course on the topic and would like to learn of similar courses or of interest in developing such a course.

3. Two frequently cited studies that explore the costs and benefits of corruption are Joseph S. Nye, Jr., "Corruption and Political Development: A Cost-Benefit Analysis," American Political Science Review, Vol. 61, No. 2 (June 1967), pp. 417-27, and Samuel P. Huntington, Political Order in Changing Societies (New Haven: Yale University Press, 1968).

\section{References}

Clarke, Michael, ed. 1983. Corruption: Causes, Consequences and Control. New York: St. Martin's Press.

The Gallup Poll Monthly, \#308, May, 1991.

Gronbeck, Bruce. 1978. "The Rhetoric of Political Corruption: Sociolinguistic, Dialectical and Ceremonial Processes." Quarterly Journal of Speech 64: 155-72.

Halayya, M. 1985. Corruption in India. New Delhi: Affiliated East-West Press Private Ltd.

The Harris Poll, May 7, 1989.

Hastings, Elizabeth H. and Philip K. Hastings, eds. 1987. Index to International Public Opinion, 1985-1986. New York: Greenwood Press.
Heidenheimer, Arnold J., Michael Johnston and Victor T. LeVine, eds. 1989. Political Corruption: A Handbook. New Brunswick: Transaction Publishers.

Johansen, Elaine R. 1990. Political Corruption: Scope and Resources, An Annotated Bibliography. New York: Garland Publishing, Inc.

Johnston, Michael. 1990. "Foreword." In Political Corruption: Scope and Resources, An Annotated Bibliography, Elaine R. Johansen, ed. New York: Garland Publishing, Inc.

Lasswell, Harold D. 1936. Politics: Who Gets What, When, How. New York: Meridian Books.

Logue, John. 1988. "Conclusion: Appreciating Scandal as a Political Art Form, or, Making an Intellectual Virtue of a Political Vice." In The Politics of Scandal: Power and Process in Liberal Democracies, Andrei Markovits and Mark Silverstein, eds. New York: Holmes \& Meier.

Markovits, Andrei, and Mark Silverstein, eds. 1988. The Politics of Scandal: Power and Process in Liberal Democracies. New York: Holmes \& Meier.

Nester, William. 1990. “Japan's Recruit Scandal: Government and Business for Sale." Third World Quarterly 12: 91-109.

New York Times, October 10, 1991.

Peck, Linda Levy. 1979. "The British Case: Corruption and Political Development in the Early Modern State." In Before Watergate: Problems of Corruption in
American Society, Abraham S. Eisenstadt, Ari Hoogenboom, and Hans L. Trefousee, eds. Brooklyn, NY: Brooklyn College Press.

Peters, John G., and Susan Welch. 1978. "Political Corruption in America: A Search for Definitions and a Theory, Or If Political Corruption Is in the Mainstream of American Politics, Why Is It Not in the Mainstream of American Politics Research?" American Political Science Review 72: 974-84.

Theobald, Robin. 1990. Corruption, Development and Underdevelopment. Durham: Duke University Press.

Ward, Peter M., ed. 1989. Corruption, Development and Inequality. London: Routledge.

Williams, Robert. 1987. Political Corruption in Africa. Brookfield, VT: Gower Publishing.

\section{About the Author}

Harvey G. Kebschull is an associate professor of political science at North Carolina State University, specializing in military coups and regimes, and in political scandals and corruption.

\title{
Revisiting the History and Objectives of Pi Sigma Alpha
}

\author{
Charles Tidmarch, Union College
}

\section{Editor's Note: The following is reprinted, with revisions, from $\mathrm{Pi}$ Sigma Alpha Newsletter 1(1), Winter, 1992.}

While some of our readers may know a bit about the history of $\mathrm{Pi}$ Sigma Alpha, many more do not, or have at least forgotten the basic facts. In view of the organization's current rededication to its purposes, it may be appropriate to review briefly the history of the national political science honor society.

Pi Sigma Alpha was founded at the University of Texas in October 1920. Formation of the society filled a longstanding need of political science students and faculty for an organization that would bring persons especially interested in the study of government into closer association with one another for their mutual benefit. Professor C. Perry Patterson was chosen to promote the society, and subsequently served as president from 1920-1932.

Pi Sigma Alpha's success on the University of Texas campus led to increased interest on other campuses, and gradually other institutions applied for and were granted chapters. In 1922 chapters were installed at the University of Oklahoma and the University of Kansas. In March 1922 , the society held its first national convention on the University of Oklahoma campus. Chapters continued to be added up until the Second World War, at which time growth was arrested temporarily. Since the post-war period expansion has proceeded at a dramatic pace. In the fall of 1991, there were more than 410 campus chapters scattered across the nation in 49 states and the District of Columbia. The society fills an important need in the advancement and diffusion of knowledge and interest among students of political science. Its position among the leading honor societies was established in 1949 through admission into membership in the Association of College Honor Societies.

Chapters receive into membership students of government, political science, public administration, and international relations, regardless of their membership in other honor societies or social organizations, when such students attain high standards of scholarship and academic distinction both in political science and in the sum total of their academic work. Faculty members teach- 
ing government, political science, public administration, or international relations in institutions with chapters are also eligible for membership.

Membership in the society may also be secured through election as an honorary member. Only distinguished persons who have made valuable contributions to political science or government are eligible for election into honorary membership.

It is the aim of Pi Sigma Alpha to be much more than a group of chapters devoted solely to the election of honor students into membership. Each chapter is encouraged to be a working organization throughout the academic year, functioning as an integral part of the political science department in the promotion of worthwhile extracurricular activities related to public affairs and scholarship in our field.

Pi Sigma Alpha promises to continue to serve the objectives stated in its constitution-"to stimulate productive scholarship and intelligent interest in the subject of government.
Pi Sigma Alpha assists in the establishment of new chapters in colleges or universities where the organization of a chapter would be mutually advantageous to the society and to the institution. Additional information concerning the procedure in petitioning for a chapter is available upon request to the national office.

A local chapter may be established at any college or university granting the baccalaureate degree or higher degrees, which is accredited by a regional or national accrediting association whose accreditation is acceptable to the Executive Council. The institution must offer a major sequence of courses in government, political science, international relations, or public administration through an appropriate administrative department or school, and must meet certain requirements as to faculty, enrollment, and autonomy. Detailed criteria are available from the Pi Sigma Alpha National Office, address below. Final decision regarding the admission of a petitioning group rests with the society's council and the member chapters.

There is no one type of institution in which the society functions best. The organization is such that highly successful chapters are maintained in many sizes and varieties of colleges and universities. Some chapters have conducted worthwhile and active programs with only a dozen active student members at any one time; others have several times this number of active members.

For information regarding the establishment of a chapter of $\mathrm{Pi}$ Sigma Alpha, please write to: $\mathrm{Pi}$ Sigma Alpha National Office, 1527 New Hampshire Avenue, N.W., Washington, DC 20036.

\section{About the Author}

Charles Tidmarch is professor of political science, Union Coliege, Schenectady, New York, and editor of Pi Sigma Alpha Newsletter.

\section{Five New Course Syllabi Collections Just Published}

\begin{abstract}
The APSA has just published the second set of five syllabi collections for political science courses, in the final year of a project supported by a grant from the Fund for the Improvement of Postsecondary Education. The project is intended to assist faculty and advanced graduate students in planning and revising syllabi for their undergraduate courses. Each collection contains around a dozen syllabi selected by an editor from a large number of submissions. The selected syllabi exemplify different approaches to the course topics as well as different institutional contexts and instructional strategies. An essay by the editor introduces syllabi in each collection with a commentary on the objectives of the particular course.

A list of the titles, editors, and
\end{abstract}

contributors to each of these new collections follows:

\section{Public Law-Edited by Lief $\mathrm{H}$.} Carter, University of Georgia.

The contributors are: Richard A. Brisbin, West Virginia University; William K. Muir, University of California-Berkeley; John E. Finn, Wesleyan University; Ron Christenson, Gustavus Adolphus College; Timothy J. O'Neill, Southwestern University; William Haltom, University of Puget Sound; David M. O'Brien, Princeton University; Herbert Kritzer, University of Wisconsin; Roy B. Flemming, Texas A\&M University; and Kim Lane Scheppele, University of Michigan.

This collection also contains excerpts from the syllabi of: Walter
Murphy, Princeton University; Leslie Goldstein, University of Delaware; Albert R. Matheny, University of Florida; David Barnum, De Paul University; Larry Baum, Ohio State University; Nancy Kassop, State University of New York-New Paltz; James Foster, Oregon State University; Dalmas H. Nelson, University of Utah; Grier Stephenson, Franklin and Marshall College; Tom Hensley, Kent State University; Stephen L. Wasby, State University of New York-Albany; Burton Atkins, Florida State University; Gerald Rosenberg, University of Chicago; Susan Olson, University of Utah; John Mueller, Luther College; Francis Graham Lee, St. Joseph's University; Mark Kessler, Bates College; Diane E. Wall, Mississippi State University. 